\title{
J-complexes of retinol formed within the nanoparticles prepared from microemulsions
}

\author{
C. Destrée • F. Debuigne $\cdot$ S. George $\cdot$ B. Champagne $\cdot$ \\ M. Guillaume • J. Ghijsen • J. B.Nagy
}

Published online: 12 August 2008

(C) Springer-Verlag 2008

\section{Erratum to: Colloid Polym Sci}

DOI 10.1007/s00396-007-1679-8

In the article an author name was missing: The second author should have been listed as F. Debuigne of the Laboratoire de RMN, Facultés Universitaires Notre-Dame de la Paix, 61, rue de Bruxelles, 5000 Namur, Belgium. Three references are missing;

(36) Debuigne, F., PhD thesis, FUNDP, Namur, Belgium 1999;

(37) Debuigne, F., Jeunieau L., Wiame M., B.Nagy J., Langmuir 2000; 16:7605;

(38) Debuigne, F., Jeunieau L., B.Nagy J. In Magnetic Resonance in Colloid and Interface Science, Fraissard J.,
Lapina O., Eds.; Kluwer Academic Publishers, Dordrecht, 2002, pp.507-512.

Reference (36) should be quoted in page 2 before reference (12) and at the end of the section entitled "revelation of the organic nanoparticles".

In page 5, line 15, references (36) and (37) should be quoted after the word "cholesterol".

In page 6, reference (36) should be added at the end of the legend of Figure 6.

In page 12, the title "Characterization of cholesterol nanoparticles by ${ }^{2} \mathrm{H}-\mathrm{NMR}$ " should be followed by indication that "most of the content of this section is reproduced from ref. (38)."

The online version of the original article can be found at http://dx.doi. org/10.1007/s00396-007-1679-8.

C. Destrée $\cdot$ F. Debuigne $\cdot$ S. George $\cdot$ J. B.Nagy $(\bowtie)$

Laboratoire de RMN,

Facultés Universitaires Notre-Dame de la Paix,

61 rue de Bruxelles,

5000 Namur, Belgium

e-mail: janos.bnagy@fundp.ac.be

B. Champagne $\cdot$ M. Guillaume

Laboratoire CTA, Facultés Universitaires Notre-Dame de la Paix,

61 rue de Bruxelles,

5000 Namur, Belgium

J. Ghijsen

Laboratoire LISE, Facultés Universitaires Notre-Dame de la Paix,

61 rue de Bruxelles,

5000 Namur, Belgium 